\title{
Hydrochemical evaluation of a heavy contaminated shallow aquifer diluted by Delice River waters, Central Anatolia, Turkey
}

\author{
M. Çelik \\ Department of Geological Engineering, Engineering Faculty, \\ Ankara University, Turkey
}

\begin{abstract}
The aim of this study is to hydrochemically evaluate the dilution with infiltrating waters from the Delice River into a shallow alluvium aquifer which is heavily contaminated. Whereas the hydrochemical content of the Delice River water has a conductivity of $1,610 \mu \mathrm{S} / \mathrm{cm}$ and total dissolved solids of $938 \mathrm{mg} / \mathrm{l}$, the hydrochemical content of the shallow aquifer groundwater displays spatial variations in conductivity (between 2,340 and $9,360 \mu \mathrm{S} / \mathrm{cm}$ ) and total dissolved solids (between 1,669 and $5,957 \mathrm{mg} / \mathrm{l}$ ).

The hydrochemical parameters $\left(\mathrm{Na}^{+}, \mathrm{SO}_{4}{ }^{2-}, \mathrm{Cl}^{-}\right.$, boron, $\left.\mathrm{HCO}_{3}^{-}\right)$, which characterise the different components of the groundwater, allowed the determination of the origin of groundwater contamination. The shallow alluvium aquifer groundwater contamination has been partly diluted by the Delice River waters.

The origin of the contamination is Çevirme Formation lithologic units, lying southwest of the study area, underlying the aquifer and consisting of claystone and gypsiferous marls.

Keywords: Delice River, shallow aquifer, surface water/groundwater relation, hydrochemistry, lithologic contamination, dilution.
\end{abstract}

\section{Introduction}

The study area, $190 \mathrm{~km}$ east of Ankara (Turkey), is located in the Kizılırmak basin (fig. 1). Surface water of the area is represented by the Delice River and Cender creek. The Delice River extends along the shallow alluvium aquifer and has a hydraulic connection with the aquifer. 


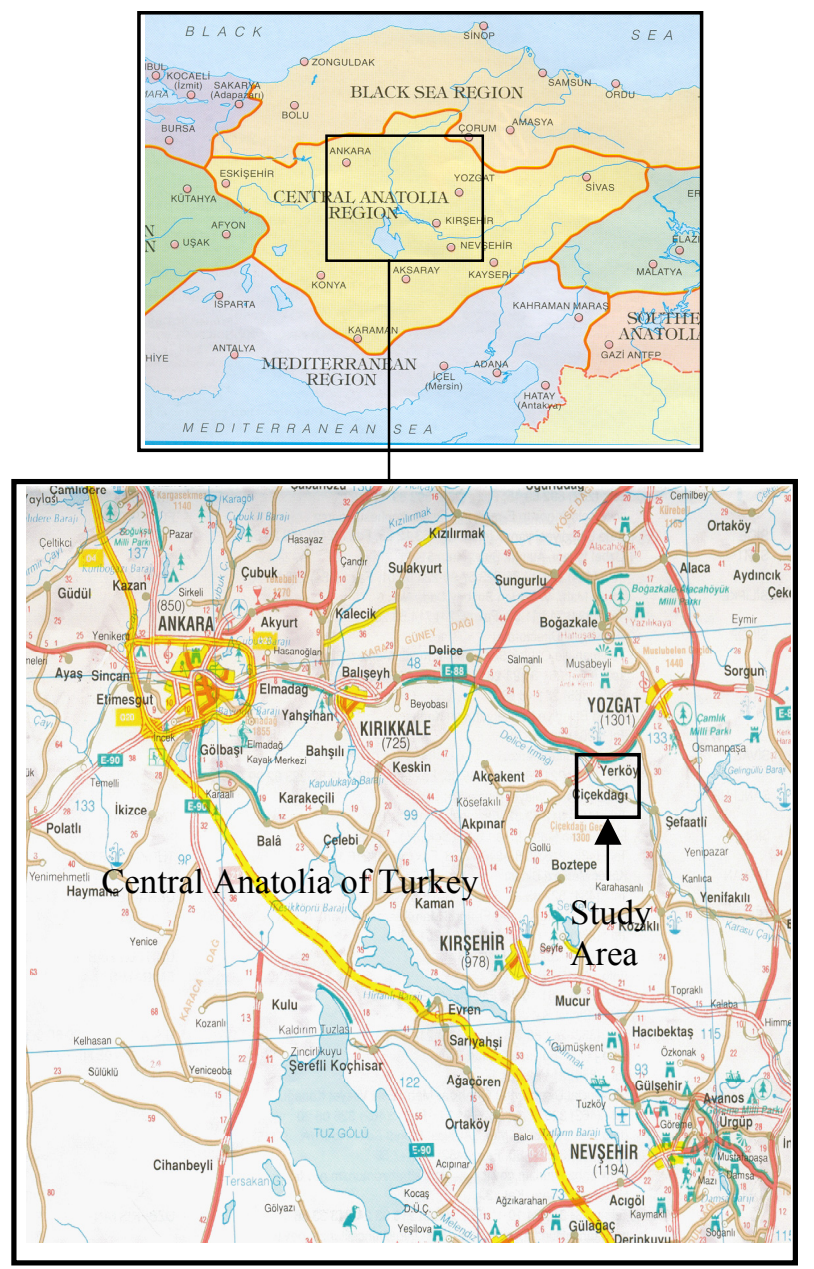

Figure 1: $\quad$ Location maps of the study area.

The aim of this study is to hydrochemically evaluate the dilution with infiltrating waters from the Delice River into the shallow alluvium aquifer which is heavily contaminated. In this regard, a total of 3 thermal and mineral, 3 surfaces and 13 groundwater samples were collected in table 1. Temperature (T), $\mathrm{pH}$, electrical conductivity (EC) and total dissolved solids (TDS) were measured in the field. Salinity problems have been also studied and suggested the best water structure in the other parts of the Kızılırmak basin (Çelik and Yıldirım [1]). 
Table 1: Hydrochemical analyses results of the waters (sampling date: 14 November 1998) (Çelik [4]).

\begin{tabular}{|c|c|c|c|c|c|c|c|c|c|c|c|c|}
\hline Sample No & $\mathrm{pH}$ & $\begin{array}{c}\mathrm{T} \\
\left({ }^{\circ} \mathrm{C}\right)\end{array}$ & $\mathrm{Ca}^{2+}$ & $\mathrm{Mg}^{2+}$ & $\mathrm{Na}^{+}$ & $\mathrm{K}^{+}$ & $\mathrm{Cl}^{-}$ & $\mathrm{SO}_{4}{ }^{2-}$ & $\mathrm{HCO}_{3}^{-}$ & $\begin{array}{l}\text { TDS } \\
(\mathrm{mg} / \mathrm{l})\end{array}$ & $\begin{array}{c}\mathrm{EC} \\
(\mu \mathrm{S} / \mathrm{cm})\end{array}$ & $\begin{array}{l}\text { Boron } \\
(\mathrm{mg} / \mathrm{l})\end{array}$ \\
\hline \multicolumn{13}{|l|}{ Cender creek } \\
\hline $\mathrm{C} 1$ & - & - & 200 & 74.4 & 635 & 19.7 & 450 & 1,220 & 256 & 2,551 & 4,230 & 1.76 \\
\hline \multicolumn{13}{|l|}{ Delice River } \\
\hline D1 & 8.0 & - & 93.6 & 29.7 & 144 & 6.8 & 154 & 179 & 349 & 876 & 1,378 & 0.30 \\
\hline D2 & 8.3 & - & 100 & 41.3 & 220 & 11.2 & 177 & 262 & 345 & 938 & 1,610 & 0.40 \\
\hline \multicolumn{13}{|c|}{ Alluvium aquifer } \\
\hline AB13 & 8.2 & 14 & 118 & 73.9 & 195 & 6.5 & 93 & 508 & 432 & 1,323 & 2,340 & 0.30 \\
\hline YK6 & 6.5 & 15.9 & 177 & 72.9 & 635 & 18.1 & 510 & 933 & 481 & 1,742 & 4,770 & 1.51 \\
\hline IHL & 8.7 & 15.4 & 94.4 & 48.1 & 465 & 20.0 & 326 & 603 & 400 & 1,994 & 3,500 & 0.97 \\
\hline SE9 & 7.5 & 16 & 128 & 84.6 & 294 & 10.0 & 246 & 563 & 479 & 1,669 & 2,760 & 0.50 \\
\hline DO4 & 7.6 & 15.9 & 124 & 62.7 & 393 & 11.3 & 336 & 544 & 471 & 1,975 & 3,420 & 0.49 \\
\hline HIP12 & 7.4 & 15.3 & 182 & 33.5 & 295 & 8.0 & 180 & 565 & 493 & 1,993 & 3,170 & 0.78 \\
\hline BG3 & 7.0 & 13.7 & 151 & 35.5 & 510 & 21.6 & 415 & 775 & 424 & 2,469 & 3,940 & 1.40 \\
\hline $\mathrm{KC} 11$ & 7.4 & 15.7 & 368 & 112 & 475 & 8.9 & 331 & 1,784 & 257 & 3,360 & 5,760 & 0.95 \\
\hline MK7 & 6.6 & 15.5 & 144 & 63.2 & 715 & 17.0 & 672 & 1,070 & 329 & 3,062 & 5,220 & 1.50 \\
\hline OA5 & 6.5 & 15.7 & 334 & 140 & 980 & 26.0 & 562 & 2,323 & 395 & 4,000 & 6,600 & 1.82 \\
\hline MK17 & 6.8 & 14.5 & 506 & 165 & 1,080 & 25.0 & 615 & 3,019 & 248 & 4,751 & 8,250 & 3.13 \\
\hline HK & 6.9 & 16.4 & 384 & 86.5 & 1,310 & 6.5 & 580 & 2,880 & 657 & 5,345 & 8,060 & 2.85 \\
\hline HK10 & 6.6 & 12.4 & 388 & 151 & 1,500 & 8.7 & 947 & 3,237 & 465 & 5,957 & 9,360 & 2.22 \\
\hline \multicolumn{13}{|l|}{$\begin{array}{l}\text { Thermal } \\
\text { waters } \\
\end{array}$} \\
\hline B1 & 6.6 & 43.7 & 154 & 1.5 & 1,500 & 115 & 2,080 & 363 & 750 & 5,324 & 8,820 & 3.46 \\
\hline U1 & 7.8 & 43 & 709 & 31 & 2,560 & 70 & 4,876 & 377 & 59 & 9,286 & 15,000 & 4.94 \\
\hline KO1 & 6.7 & 36 & 1,260 & 12 & 4,320 & 120 & 7,749 & 305 & 73 & 13,762 & 19,600 & 7.44 \\
\hline
\end{tabular}

\section{Hydrogeology and hydrology}

Gündüz [2] explained that the oldest rock in the study area is composed of rhyolite, rhyodasite, and dacite. These units, called the Kötüdağ volcanite member, are fractured and fissured. Canik [3] states that the contact between the 
volcanite member and granites is suitable for deep groundwater circulation by means of permeability. The Çevirme Formation, consisting of conglomerate, limestone, claystone, and gypsiferous marls, unconformable overlies the Kötüdağ volcanite member. This formation is overlain by the Delicerrmak Formation, which is composed of conglomerate, sandstone and siltstone (fig. 2). The alluvium is composed of gravel, sand and clay sized materials. According to Çelik [4], while the Delice River recharges into the alluvium aquifer about at the centre of the river (near D2), the Delice River is recharged by alluvium aquifer at the lower part of the river (fig. 3).

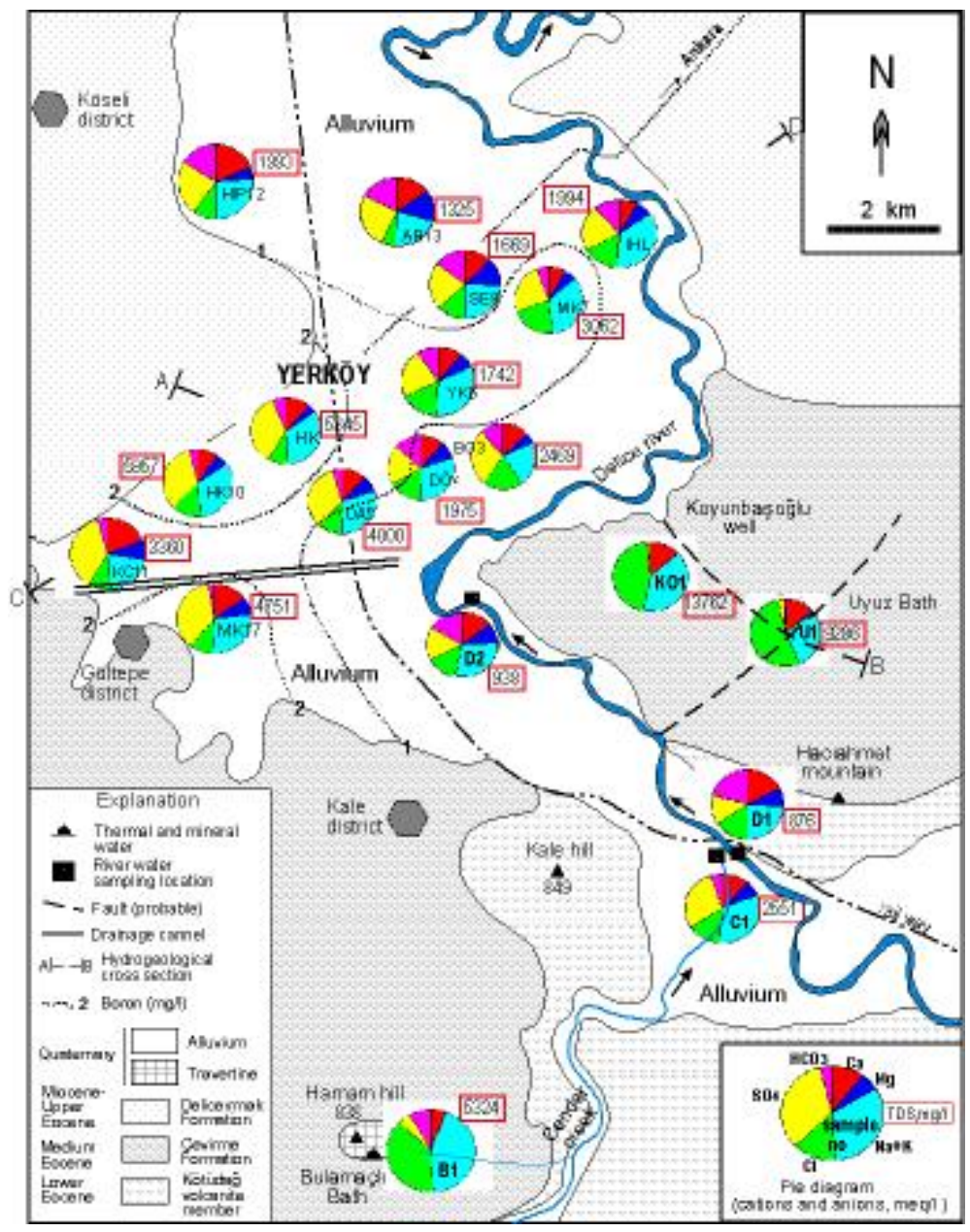

Figure 2: $\quad$ Hydrogeological map of the study area.

There are three types of waters in the study area. Those are surface waters, shallow alluvium aquifer waters and, thermal and mineral waters. The Delice 
River and the Cender Creek comprise the surface water network of the study area. The Cender Creek joins the Delice River in the southeast of the area. The Delice River flows through the eastern part of the alluvium aquifer (fig. 2). Discharge of the Cender Creek is estimated as 10-30 1/s. On the basis of measurements conducted at D1 site of the Delice River, discharge was found to be 4.94 and $9.47 \mathrm{~m}^{3} / \mathrm{s}$ for November 1998 and May 1999, respectively by Çelik [4]. Wells drilled in the alluvium aquifer are generally shallow $(10-15 \mathrm{~m})$. Bulamaçlı bath (B1), Uyuz bath (U1) and Koyunbaşoğlu bath (KO1) are of thermal and mineral waters. According to Canik [3], Bulamaçlı bath spring issues through the fault. Discharge of the spring is $1.45 \mathrm{l} / \mathrm{s}$ and its temperature is $44.5^{\circ} \mathrm{C}$. According to Gündüz [2], the well for the Uyuz bath is located on two buried faults (fig. 2). The water temperature of Koyunbaşoğlu well was measured as $36^{\circ} \mathrm{C}$ in November 1998 and $36.9^{\circ} \mathrm{C}$ in May 1999 (Çelik [4]).

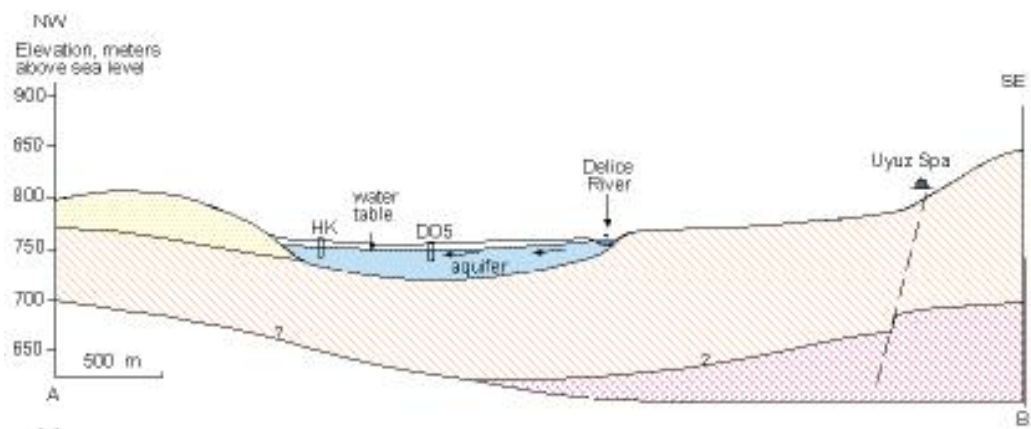

(a)

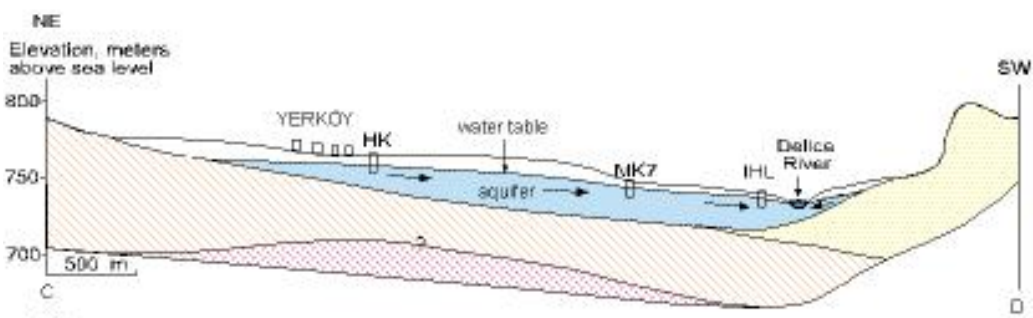

(b)

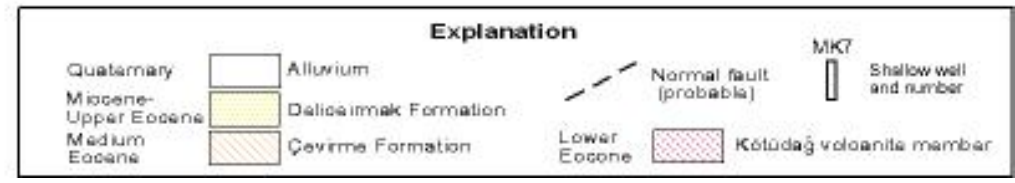

Figure 3: Hydrogeological cross-sections of the study area (modified from Çelik [4]). 


\section{Hydrochemical evaluations}

On the basis of results of the water analyses, Schoeller diagram is drawn (fig. 4). Thermal and mineral waters have $\mathrm{Na}^{+}$and $\mathrm{Cl}^{-}$hydrochemical facies $\left(\mathrm{Na}+\mathrm{K}>\mathrm{Ca}>\mathrm{Mg} ; \mathrm{Cl}>\mathrm{SO}_{4}>\mathrm{HCO}_{3}\right)$. The Delice River waters have dominant $\mathrm{Na}^{+}$ cation, but have not any dominant anion (fig. 4). The anions are about same level in the river waters. Shallow alluvium aquifer waters have about same hydrochemical facies $\left(\mathrm{Na}^{+}\right.$and $\left.\mathrm{SO}_{4}{ }^{2-}\right)$. According to Schoeller diagram, thermal and mineral waters are a different water type from the Delice River and the alluvium aquifer waters.

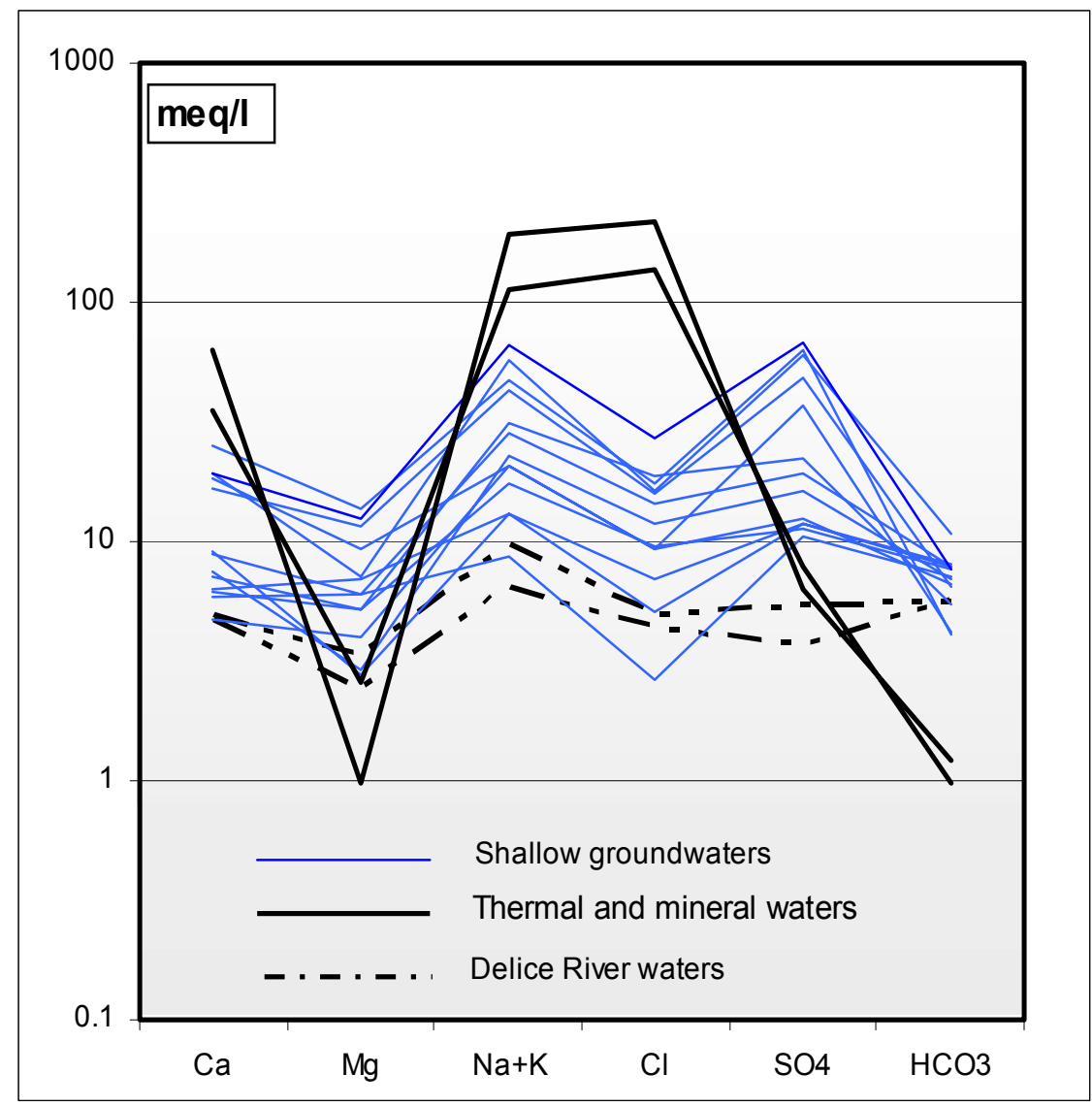

Figure 4: Schoeller diagram of the waters in the study area.

Also, pairs of measured parameters are plotted in x-y diagrams (composition diagrams). The data plot is on straight lines, revealing a positive correlation of $\mathrm{Ca}, \mathrm{Mg}, \mathrm{Na}, \mathrm{Cl}$ and $\mathrm{SO}_{4}$ with TDS (fig. 5). Especially, strong correlations exist between Na-TDS ( $\mathrm{R}^{2}: 0.88$; R: 0.93), $\mathrm{SO}_{4}$-TDS ( $\mathrm{R}^{2}: 0.94$; $\left.\mathrm{R}: 0.97\right)$. Whereas, ion 
concentrations of $\mathrm{Na}$ and $\mathrm{SO}_{4}$ are the lowest in the Delice River (D2), the ion concentrations are the highest in the alluvium aquifer well (Well no. HK10) (fig. 6). Therefore the Delice River (D2) and the alluvium aquifer samples (Well no. HK10) may be end members. Mixing rate calculations was made between the Delice River waters and the alluvium aquifer waters (fig. 7). Equation (1) can be written as follows (Mazor [5]).

$$
\mathrm{C}_{\mathrm{s}}=\mathrm{C}_{\text {end member1 }} \mathrm{X}+\mathrm{C}_{\text {end member2 }}(1-\mathrm{X})
$$

$\mathrm{C}_{\mathrm{s}} \quad$ : ion concentrations of samples (meq/l)

$\mathrm{C}_{\text {end member } 1} \quad$ : ion concentration of the first end member (meq/l)

$\mathrm{C}_{\text {end member2 }}$ : ion concentration of the second end member (meq/l)

$\mathrm{X}$ : mixing rate $(\%)$.
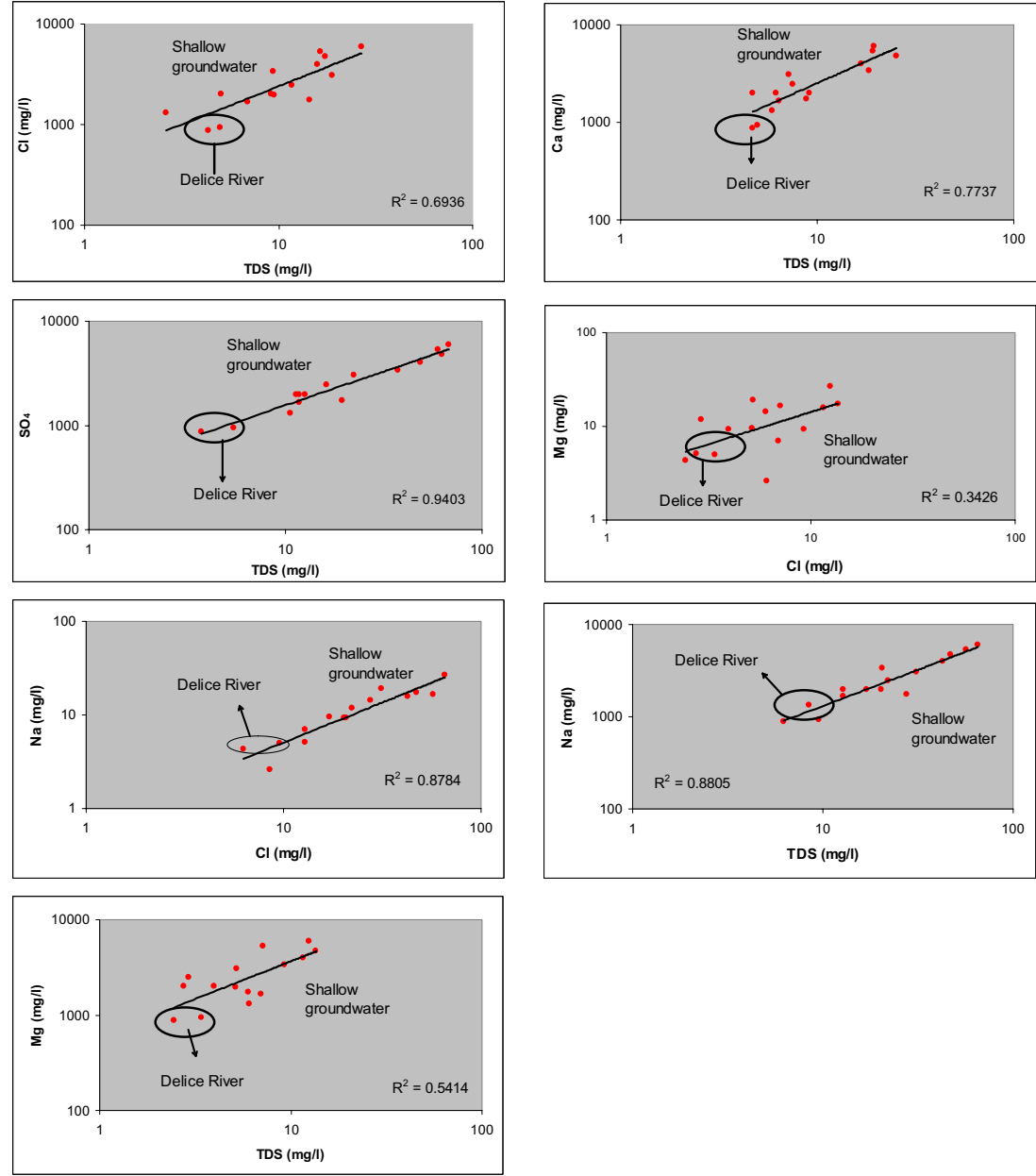

Figure 5: Compositional diagrams of the shallow alluvium aquifer groundwaters and the Delice River samples (Total dissolved solids and the ions are of $\mathrm{mg} / \mathrm{l}$ ). 


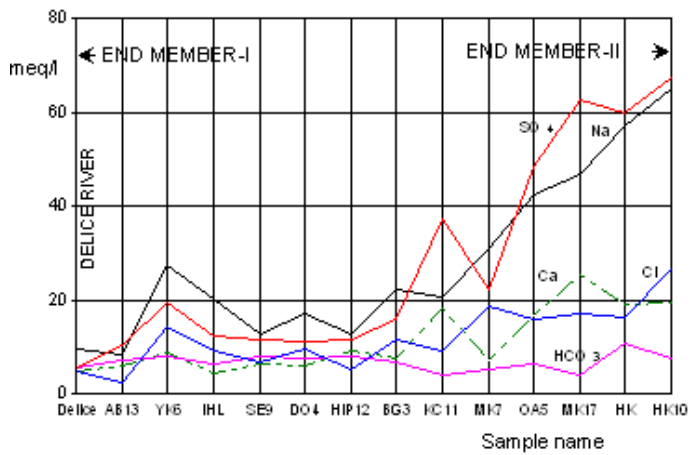

Figure 6: Variation of the ions (anion and cation) between end member-I and end member-II.

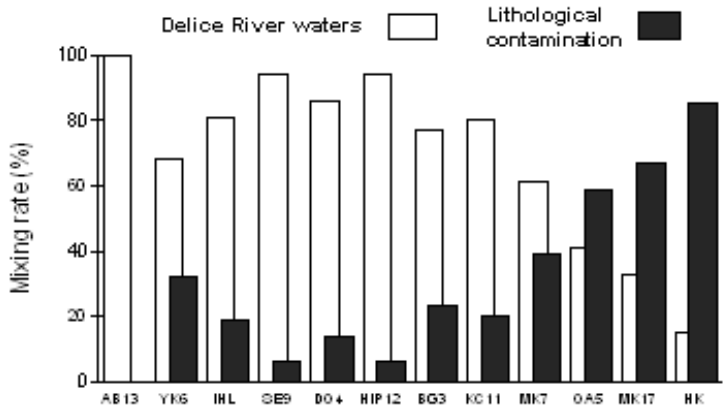

(A)

Sample name

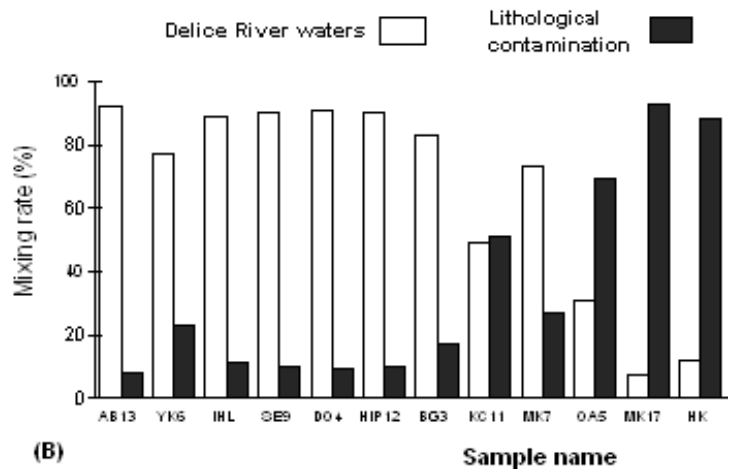

Figure 7: Sodium (A) and sulphate (B) mixing rates into the shallow alluvium aquifer well waters from the Delice River waters. 
Since the major ions of $\mathrm{Na}$ and $\mathrm{SO}_{4}$ have been typically increased through the alluvium aquifer, mixing rate calculations are conducted for these ions. According to the mixing calculations, a lot of well waters (AB13, YK6, IHL, SE9, DO4, HIP12 and BG3) have been fairly diluted by the Delice River waters. A few wells have been contaminated by lithology. These are of MK7, KC11, OA5, MK17 and HK wells (fig. 7). According to Mazor (1991) [5], clay and shale rocks often contain salt and gypsum. The rocks have high salinity (900-2,000 mg/l), $\mathrm{Cl}^{-}$dominant anion, followed by $\mathrm{SO}_{4}$ and $\mathrm{Na}$ major cation. Gypsum has high salinity $(2,000-4,000 \mathrm{mg} / \mathrm{l})$, dominant anion is $\mathrm{SO}_{4}$, dominant cation is $\mathrm{Ca}$, followed by $\mathrm{Mg}$ and $\mathrm{Na}$. Salinity (TDS) is between 1,669 and $5,957 \mathrm{mg} / \mathrm{l}$ in the study area. As the major ions have been diluted by the Delice River waters, also boron contamination of the alluvium aquifer has been decreased by the same way. A solute in water will move from an area of greater concentration towards an area where it is less concentrated. This process is known as molecular diffusion. The diffusion will occur as long as a concentration gradient exists, even if the fluid is not moving, which can be expressed as Fick's first law (Fetter [6]). The origin of the high salinity and the boron contamination of the alluvium aquifer are Çevirme Formation units which are mainly claystone and gypsiferous marls. The contaminated shallow alluvium aquifer area is about $130 \mathrm{~km}^{2}$ in the Yerköy plain.

\section{Conclusions}

Whereas the hydrochemical content of the Delice River water has a conductivity of $1,610 \mu \mathrm{S} / \mathrm{cm}$ and total dissolved solids of $938 \mathrm{mg} / \mathrm{l}$, the hydrochemical content of the shallow aquifer groundwater displays spatial variations in conductivity (between 2,340 and 9,360 $\mu \mathrm{S} / \mathrm{cm}$ ) and total dissolved solids (between 1,669 and $5,957 \mathrm{mg} / \mathrm{l})$.

The hydrochemical parameters $\left(\mathrm{Na}^{+}, \mathrm{SO}_{4}{ }^{2-}, \mathrm{Cl}^{-}\right.$, boron, $\left.\mathrm{HCO}_{3}^{-}\right)$, which characterise the different components of the groundwater, allowed the determination of the origin of groundwater contamination. The shallow alluvium aquifer groundwater contamination has been diluted by the Delice River waters. According to mixing calculations, a lot of wells (AB13, YK6, IHL, SE9, DO4, HIP12 and BG3) have been fairly diluted by the Delice River waters. A few wells have been contaminated by lithology. These are of MK7, KC11, OA5, MK17 and HK wells.

The origin of the contamination is Çevirme Formation lithologic units, lying southwest of the study area, underlying the aquifer and consists of claystone and gypsiferous marls.

In order to remediate the waters of the shallow alluvium aquifer, firstly $\mathrm{Na}$, $\mathrm{SO}_{4}$ and boron ions may be diluted by the Delice River waters. For this, irrigation strategy may be applied in the Yerköy plain with pumping from channels recharged from the Delice River. 


\section{References}

[1] Çelik, M. \& Yıldırım, T., Hydrochemical evaluation of groundwater quality in the Çavuşçayı basin, Sungurlu-Çorum, Turkey, Environmental Geology, 50(3), pp. 323-330, 2006.

[2] Gündüz, M., Hydrogeological investigation of Güven (Uyuz) bath, Yerköy, Yozgat, (in Turkish), Mineral Research and Exploration Institute Report, No. 9595, Ankara, 1993.

[3] Canik, B., Hydrogeological investigation of Bulamaçlı bath (Çiçekdağ1, Kırşehir) (in Turkish), Mineral Research and Exploration Institute Journal, 93/94, pp. 118-136, 1982.

[4] Çelik, M., Water quality assessment and the investigation of the relationship between the River Delice and the aquifer systems in the vicinity of Yerköy (Yozgat, Turkey), Environmental Geology, 42(6), pp. 690-700, 2002.

[5] Mazor, E., Applied Chemical and Isotopic Groundwater Hydrology, Open University Press: Buckingham, pp. 264, 1991.

[6] Fetter, C. W., Contaminant Hydrogeology, Macmillan Publishing Company: New York, pp. 458, 1993. 